\title{
Shear-wave velocity structure from MASW and SPAC methods. The case of Adra town, SE Spain
}

\author{
P. Martínez-Pagán ${ }^{1, *}$, M. Navarro ${ }^{2,6}$, J. Pérez-Cuevas ${ }^{3}$, F.J. Alcalá ${ }^{4,5}$, A. García-Jerez ${ }^{2,6}$, \\ and F. Vidal ${ }^{6}$ \\ ${ }^{1}$ Universidad Politécnica de Cartagena, Murcia, Spain \\ ${ }^{2}$ University of Almería, Spain \\ ${ }^{3}$ Pontificia Universidad Católica Madre y Maestra Santo Domingo, Dominican Republic \\ ${ }^{4}$ Catholic University of Murcia, Spain \\ ${ }^{5}$ Instituto de Ciencias Químicas Aplicadas, Facultad de Ingeniería, Universidad Autónoma de \\ Chile, Chile \\ ${ }^{6}$ Instituto Andaluz de Geofísica, University of Granada, Spain
}

Running title: Shear-wave velocity structure from MAWS and SPAC methods

\author{
*Corresponding author \\ P. Martínez-Pagán
}

${ }^{1}$ Departamento de Ingeniería Minera, Geológica y Cartográfica, Universidad Politécnica de Cartagena (UPCT), Paseo Alfonso XIII, 52, 30203 Cartagena, Murcia, Spain

\author{
Phone: +34 968325558 \\ Fax: +34968325435 \\ E-mail: p.martinez@upct.es
}

\begin{abstract}
This is the peer reviewed version of the following article: [Martínez-Pagán P., M. Navarro, J. Pérez-Cuevas, F. J. Alcalá, A. García-Jerez and F. Vidal (2018) Shear-wave velocity structure from MASW and SPAC methods: The case of Adra town, SE Spain, Near Surface Geophysics 16(3), 356 - 371], which has been published in final form at [https://doi.org/10.3997/1873-0604.2018012]. This article may be used for non-commercial purposes in accordance with Wiley Terms and Conditions for Use of Self-Archived Versions.
\end{abstract}




\title{
Shear-wave velocity structure from MASW and SPAC methods. The case of Adra town, SE Spain
}

\begin{abstract}
The damage distribution in the town of Adra (south-eastern Spain) during the 1993 and 1994 Adra earthquakes, magnitude Mw 5.0 and maximum intensity degree of VII (European Macroseismic Scale), was mainly concentrated in the southeast sector, where low-diagenetic (soft) sediments outcrop. As new urbanizations are planned in that sector, a soil classification based on the shallow shear-wave velocity (Vs) structure is needed. For the purpose of earthquake disaster mitigation, the Spatial Autocorrelation (SPAC) and the Multichannel Analysis of Surface Waves (MASW) methods were used to propose integrated 2D Vs models for the seismic response characterization of shallow geology. Joint inversion of $\mathrm{H} / \mathrm{V}$ spectral ratios of ambient noise, interpreted under the Diffuse Field Approach, and dispersion curves derived from the SPAC method allowed to obtain more constrained models. Both, SPAC and MASW methods provided similar results for the surveyed geological formations. From these models, a classification of the geological formations has been carried out in terms of Vs30 values and Eurocode 8 (EC8, 1998) classes. Lower Vs30 values in the $180-360 \mathrm{~m} / \mathrm{s}$ range were found in the southeastern sector of the town, where soft sediments outcrop and some building damage was reported from the 1993-1994 earthquakes. The highest Vs30 values above $800 \mathrm{~m} / \mathrm{s}$ appear at the northern sector, where the hardest rocks outcrop and no building damage was reported. The combination of the well-suited Vs database prepared for different geological formations with the 1:5,000 scale geological mapping was a step to obtain a detailed soil microzonation map of Adra. It gives a new predictive insight into the building damage distribution, which will contribute to the appropriate urban planning of the future growth of the town.
\end{abstract}

Keywords: Spatial autocorrelation (SPAC) method, Multichannel analysis of surface waves (MASW) method, geological mapping, Vs30, site amplification, Adra town.

\section{Introduction}

Southeastern Spain is the zone with the highest seismic hazard in the Iberian Peninsula (Fig. 1a), as pointed out by Vidal (1986). In this region, Adra typifies a medium-size town of 24,700 inhabitants with historical seismic records. The town recorded the complete destruction of most buildings during an earthquake in 1522 with intensity $\mathrm{I}_{\mathrm{EMS}}=\mathrm{IX}$ in the European Macroseismic Scale (EMS scale) (Benito et al. 2007). During the 1993 and 1994 small earthquakes (magnitude Mw 5.0) several buildings, mainly sited in the southeastern sector of the town, suffered grade 3 damage (EMS scale), whereas grade 2 damage was reported for many buildings across the whole town (Navarro et al. 2007, Fig. 1b). Since new urbanizations were planned in southeastern sectors characterized by low-diagenetic (soft) geological materials susceptible of seismic amplifications (Alcalá et al. 2002; Navarro et al. 2002, 2007) Civil Defence of Adra promoted seismic microzonation studies as an essential tool to identify the factors influencing the building damage distribution. 


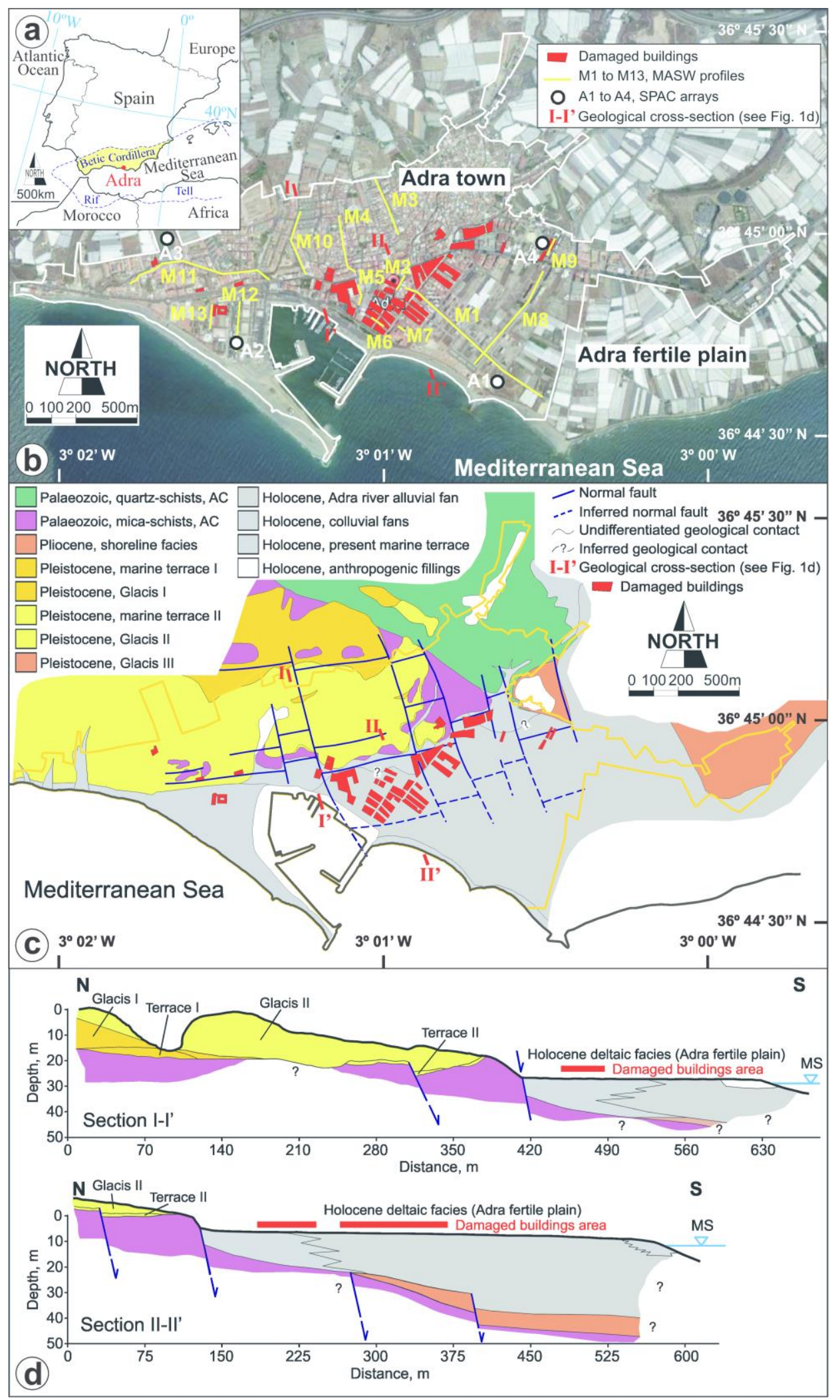

Fig. 1. (a) Location of Adra town within the Alpine Betic Cordillera in southeastern Spain. (b) Building damage distribution after the 1993 and 1994 Adra earthquakes, modified from Navarro et al. (2007); SPAC arrays (labeled from A1 to A4), MASW profiles (labeled from M1 to M13), and two geological cross-sections (labeled I-I' and II-II') are included. (c) Geological map of Adra at scale 1:5,000, modified from Alcalá et al. (2002). (d) Geological cross-sections I-I' and II-II', modified from Alcalá et al. (2002) and Navarro et al. (2007); legend for geological materials as in (c). AC: Alpujárride Complex. MS: Mediterranean Sea. 
Within this framework, the shallow shear-wave velocity (Vs) has become a good quantitative indicator of geological material stiffness, useful for soil microzonation of urban areas for earthquake disaster mitigation (Martínez-Pagán et al. 2014). Vs is a key parameter in dealing with mechanical properties of subsurface materials (Olona et al. 2010; Duffy et al. 2014; Lorenzo, Hicks and Vera 2014; Yilmaz 2015), ground amplification, and liquefaction potential phenomena in earthquake events (Chang et al. 2011; Tarque et al. 2013; Vella, Galea and D'Amico 2013). Vs models have been applied to seismic hazard assessment since ground amplification, which may cause most earthquake-related damages, often changes with shallow ground stiffness (Park, 2013). In particular, the National Earthquake Hazard Reduction Program (NEHRP 2001) in the USA and the Eurocode 8 (EN 1998) in Europe adopted the average Vs in the top $30 \mathrm{~m}$ (usually denoted by Vs30) as the fundamental ground parameter to be considered for the structural design of buildings against earthquake events (Mahajan 2009). Actually, the International Building Code (IBC) published the same classes in 2000 (Martínez-Pagán et al. 2014). This is based on the premise established from empirical studies that the top $30 \mathrm{~m}$ comprise the most influential layers for the shaking ground response (Park 2013). In general, a site with a lower Vs30 would be subjected to a greater ground amplification. The Spatial Autocorrelation (SPAC) (Aki 1957), the inversion of Horizontal-to-Vertical spectral ratio (HVSR) of ambient noise (e.g. García-Jerez et al. 2016) and the Multichannel Analysis of Surface Waves (MASW) (Park, Miller and Xia 1999) are different methods widely used to provide 1D and 2D Vs models of subsurface geological materials which can be integrated for Vs30 subsurface classification maps. The MASW method (Park et al. 1999; Xia, Miller and Park 1999) has been applied to a wide range of geotechnical problems for mapping the 2D Vs structure (Suto 2013), such as detecting cavities (Miller et al. 1999), searching for bedrock structure (Carnevale et al. 2005), examining water seepage (Ivanov et al. 2006), monitoring ground improvement (Burke and Schofield 2008), and recently, in earthquake hazard studies (Sairam et al. 2011; Eker, Akgün and Koçkar 2012; Kolat, Ulusay and Suzen 2012; Panzera and Lombardo 2013; Martínez-Pagán et al. 2014).

The MASW method depends on Rg-wave analysis for retrieving near-surface Vs models. Usually based on the inversion of surface-wave dispersion curves by local 1D forward modelling, the MASW method has often been applied to laterally varying sites (Boiero et al. 2013) as well as on long and continuous seismic lines or profiles (Martínez-Pagán et al. 2014). The SPAC is a passive-source method which takes advantage of the energy in the elastic waves which make up the ambient noise wavefield. These surveys are often performed by using high-quality seismometers with good signal-to-electronic noise ratios down to low frequencies, 2D array setups which account for possible anisotropic ambient source distribution, and longer recording time. Like MASW, the standard SPAC method involves Rayleigh-wave dispersion curve retrieval from vertical-component records. Recent extensions to 3-component analysis have been developed by García-Jerez et al. (2008a, 2010) and García-Jerez, Luzón and Navarro (2008b). The HVSR was proposed by Nakamura (1989) as a rough estimation of the seismic response of the subsoil from three-component records of ambient noise at a single seismic station. Recently, sophisticated modelling and inversion schemes have been developed to take full advantage of the HVSR(f) curve for subsurface investigation. Since this quantity is very sensitive to the presence of sharp seismicvelocity contrasts, combination of HVSR and dispersion curves in joint inversion schemes provides better constrained models. 
In this article, punctual 1D- and continuous 2D-Vs models of subsurface geological materials are derived from SPAC and MASW methods, and used to build up the Vs30 subsurface classification map of Adra town. To this end, four SPAC arrays were performed at open spaces providing a 1D Vs model at each site. Vs cross-sections were performed from MASW surveys along main streets of Adra, passing through the SPAC array sites. The detailed 1:5,000 scale geological map performed by Alcalá et al. (2002) was of assistance to support (1) the selection of sites for SPAC and MASW surveys, (2) the accurate interpretation of Vs models, and (3) the discussion of the integrated Vs30 map. The Vs models and the existing soil predominant period map have been compared and therefore used for interpretation of the damage distribution reported by Navarro et al. (2007).

This paper is organized as follows. Section 2 comprises the geological setting of the study area. The field methods and analytical procedures for SPAC and MASW methods are introduced in Section 3. Section 4 contains the results of the geophysical surveys and the derived maps. The relationship between Vs30 distribution and the local geology is discussed in Section 5. Finally, the main conclusions are presented in Section 6.

\section{Geographical and geological setting}

Adra is a coastal town located in the Almeria province in southeastern Spain $\left(3^{\circ} 00^{\prime}-3^{\circ} 02^{\prime} \mathrm{W}, 36^{\circ} 44^{\prime} 30^{\prime \prime}-36^{\circ} 45^{\prime} 00^{\prime \prime} \mathrm{N}, 0-50\right.$ m.a.s.1.). Irrigated agriculture in greenhouses is the main economic driver, which has attracted new population in last years. As a consequence, new urbanizations have occupied the fertile plains traditionally devoted to irrigated crops in the south-eastern sector of the town (Fig. 1b). The Spanish National Institute for Statistics (INE 2017) reported 24,700 inhabitants in 2017.

From a geological point of view (Fig. 1a), the study area belongs to the Alpujárride Complex from the Internal Zone of the Betic Cordillera (Aldaya, Baena and Ewert et al. 1983; Sanz de Galdeano 1997; Alcalá et al. 2002). As a consequence of the convergence between the African and Eurasian Plates, a great displacement of crustal and sub-crustal (Internal Betic Zone) took place ending with the collision of the Internal and External Betic Zones during the early Miocene (Sanz de Galdeano et al. 1995; Alcalá et al. 2013). In the study area, the active tectonics controls the basement uplift rate and faulting style, the combination of the active tectonics and sea-level changes control the accommodation space for the Late Miocene and Quaternary sedimentary record (Goy and Zazo 1986; Sanz de Galdeano et al. 1995), and some human-induced actions have determined high erosion and sediment-supply rates during the last 2.500 years (Alcalá et al. 2002; Paz et al. 2017). This combination of natural and humaninduced geological processes controls the spatial distribution and ranges of Vs in southeastern Spain urban areas (Benito et al. 2007; García-Jerez et al. 2007; Navarro et al. 2007, 2014; Martínez-Pagán et al. 2014).

Alcalá et al. (2002) classified the geological record of Adra town into twelve geological formations attending to age, origin, geometry, and mechanical properties reported by Aldaya et al. (1983), Goy and Zazo (1986), Sanz de Galdeano et al. (1995), and Navarro et al. (2002). The two pre-orogenic formations included low to medium grade metamorphic hard rocks (basement) as Palaeozoic mica-schists and quartz-schists. The ten post-orogenic formations included Pliocene to Quaternary sediments 
unconformably deposited over the basement from East to West in the middle and southern sectors of the town (Figs. 1c and 1d). Based on the different (often low to very low) diagenetic degree and mechanical properties, Alcalá et al. (2002) classified these post-orogenic formations as: (1) a Pliocene shoreline deltaic formation composed of poorly rounded pebbles into a sandy-clayey matrix at the eastern sector; (2) five Pleistocene continental and marine formations disposed as alternation of three generations of continental glacis composed by fine silts, sands, and gravel into a red silty-clayey matrix, and two sandy and gravel-rich marine terraces at different elevation with respect to current sea level; and (3) four Holocene formations as: (a) Adra river alluvial fan deposits composed by fine sands, silts, and gravel and located at the eastern sector; (b) colluvial fan deposits filling the gullies that mark the town from East to West; (c) present marine terrace composed of fine sands; and (d) anthropogenic fillings.

This detailed geological background is the basis for a predictive Vs distribution in Adra town (Navarro et al. 2007). Attending to common mechanical properties deduced from geotechnical surveys, Alcalá et al. (2002) classified the twelve preorogenic and post-orogenic formations into nine geological-seismic formations (Table 1). From $55 \mathrm{~N}$-values from 30 standard penetration tests (SPT) and 49 real density values (dry estimation), tentative ranges of Vs for post-orogenic Pliocene to Quaternary sediments (Table 1) were deduced by using the expressions of Imai (1981) and Kokusho (1987). The rationale used for the classification of twelve geological formations and nine geological-seismic formations is described in Alcalá et al. (2002) and partially in Navarro et al. $(2002,2007)$.

Table 1. Clustering of the twelve geological formations identified in Adra town into nine geological-seismic formations as in Alcalá et al. (2002) and Navarro et al. (2007). The tentative average Vs value for each geological-formation seismic was deduced from Imai (1981) and Kokusho (1987) expressions.

\begin{tabular}{|c|c|c|c|c|c|c|c|c|}
\hline ID & $\begin{array}{l}\text { Geological-seismic Formation } \\
\text { (a) }\end{array}$ & Age & Lithology & $\begin{array}{l}\text { Thiclmess (m) } \\
\text { (b) }\end{array}$ & $\begin{array}{l}\text { N-value (dmnl) } \\
\text { (b) }\end{array}$ & $\begin{array}{l}\text { Density }\left(\mathrm{gr} \mathrm{Cm}^{3}\right) \\
\text { (b) }\end{array}$ & $\frac{V_{s}\left(m^{-1}\right)}{(c) \text { (d) }}$ & $\begin{array}{l}\text { Underlying } \\
\text { formation } \\
\end{array}$ \\
\hline 01 & Mica-schists & Palaeozoic & Crystalline hard rock & & $\begin{array}{l}>50 \\
\rho 50)\end{array}$ & & & \\
\hline 02 & Quartz-schists & Palaeozoic & Crystalline hard rock & & $\begin{array}{l}>50 \\
(e 50)\end{array}$ & & & 01 \\
\hline 03 & Shoreline facies & Pliocene & $\begin{array}{l}\text { Clayey sands and } \\
\text { gravels }\end{array}$ & $\begin{array}{l}>20 \\
(5)\end{array}$ & $\begin{array}{l}>50 \\
(50)\end{array}$ & $\begin{array}{l}1.90-1.95 \\
(1.91)\end{array}$ & 389402 & 01,02 \\
\hline 04 & Marine terraces I and II & Pleistocene & Medium and thick sands & $\begin{array}{l}1-5 \\
(2)\end{array}$ & $\begin{array}{l}30-35 \\
(32)\end{array}$ & $\begin{array}{l}1.75-1.80 \\
(1.80)\end{array}$ & $297 \quad 317$ & 01,02 \\
\hline 05 & Glacis I, II, and III & Pleistocene & $\begin{array}{l}\text { Clayey sands and } \\
\text { gravels }\end{array}$ & $\begin{array}{l}1-50 \\
(12)\end{array}$ & $\begin{array}{l}35-50 \\
(41)\end{array}$ & $\begin{array}{l}1.80-1.90 \\
(1.80)\end{array}$ & $340 \quad 344$ & $01,02,04$ \\
\hline 06 & Colluvial fans & Holocene & Gravels and sands & $\begin{array}{l}1-5 \\
(2.5)\end{array}$ & $\begin{array}{l}25-30 \\
(27)\end{array}$ & $\begin{array}{l}1.80-1.85 \\
(1.82)\end{array}$ & $240 \quad 240$ & 01,02 \\
\hline \multirow{2}{*}{07} & \multirow{2}{*}{ Adra river alluvial fan } & \multirow{2}{*}{ Holocene } & Fine silts and sands & $\begin{array}{l}1-5 \\
(3.5) \\
\end{array}$ & $\begin{array}{l}15-20 \\
(18)\end{array}$ & $\begin{array}{l}1.85-1.90 \\
(1.88)\end{array}$ & $266 \quad 262$ & \multirow[t]{2}{*}{$-01,02,03,05$} \\
\hline & & & Gravels and sands & $\begin{array}{l}1-50 \\
(22)\end{array}$ & $\begin{array}{l}30-40 \\
(34)\end{array}$ & $\begin{array}{l}1.80-1.90 \\
(1.83)\end{array}$ & $259 \quad 259$ & \\
\hline 08 & Present marine terrace & Holocene & Fine to thick sands & $\begin{array}{l}>15 \\
(7)\end{array}$ & $\begin{array}{l}15-20 \\
(17)\end{array}$ & $\begin{array}{l}1.75-1.85 \\
(1.81)\end{array}$ & 205205 & $01,02,04,05,07$ \\
\hline 09 & Anthropogenic fillings & Holocene & Blocks and gravels & $\begin{array}{l}1-6 \\
(4)\end{array}$ & $\begin{array}{l}<10 \\
(8)\end{array}$ & $\begin{array}{l}<1.70 \\
(1.65)\end{array}$ & 160160 & All \\
\hline
\end{tabular}

(a) Definition of original Geological Formation, age, and lithology as in Fig. 1c (b) Range of measured data and average value into parenthesis.

(c) Vs by Imai (1981)

(d) Vs by Kokusho (1987)

\section{Methods}

The methodology chosen in this study, which is based on shear-wave velocity measurements, relied on two seismic methods: the MASW method (Park et al. 1999; Xia et al. 1999), and the SPAC method (Aki 1957) enhanced with the inversion of the horizontal-to-vertical spectral ratio (HVSR) of ambient noise for diffuse wavefields (Sánchez-Sesma et al. 2011). 


\subsection{SPAC method and inversion of HVSR of ambient noise}

The SPAC measurements were carried out at four open spaces, hereafter called A sites (Fig. 1b). Vertical ground motion components excited by ambient noise were recorded at the surface by using circular-shaped arrays. For this, five high-sensitivity VSE-15D sensors surrounding a sixth central sensor with the same characteristics (Fig. 2a) and a SPC-35 digitizer (Fig. 2b) were used. This system provides an acceptable response for frequencies between 0.25 and $70 \mathrm{~Hz}$. Additional 3-component measurements were carried out at the array centres to compute the HVSR of ambient noise. The array radii (r) ranged from 3 to $25 \mathrm{~m}$. Different radii were used depending on the thickness of existing geological formations, available geophysical data, and dimension of the enabled open areas (Table 2). Longest wavelengths which should be resolved with the SPAC method are in the order of $\lambda_{\max } \sim 15-16 r_{\max }$ (SESAME, 2005). The expected maximum investigation depth $\left(\mathrm{Z}_{\max }\right)$ is between $\lambda_{\max } / 3$ and $\lambda_{\max } / 2$. The aliasing limitations of the SPAC method are expressed by the oscillating nature of the Bessel function, showing multiple solutions for arguments larger than $~ 3.6$. Thus, given a dense azimuthal sampling of the wavefield, the aliasing wavelength is approximately given by $\lambda_{\min } \sim 1.8 \mathrm{r}_{\min }$ (SESAME, 2005).

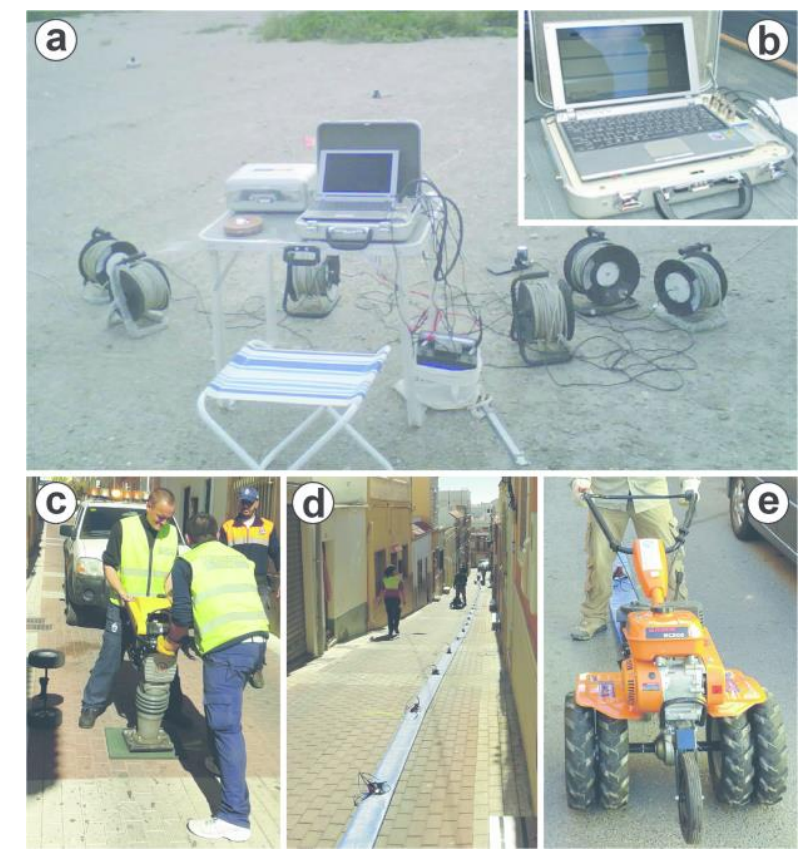

Fig. 2. (a) SPAC sensors deployment at an open site. (b) SPC-35 digitizer. (c) Portable vibrator seismic source. (d) Land-streamer system with the geophones being towed through streets. (e) Small tractor situated at the head of the land-streamer to easily move all the system.

Table 2. Characteristics of the SPAC array setup and dispersion curves at the array sites.

\begin{tabular}{|c|c|c|c|c|c|c|c|}
\hline SPAC & $\begin{array}{c}\text { Radii } \\
(\mathrm{m})\end{array}$ & $\begin{array}{c}\Delta \mathrm{f} \\
(\mathrm{Hz})\end{array}$ & $\begin{array}{c}\Delta \mathrm{c}_{\mathrm{R}} \\
\left(\mathrm{ms}^{-1}\right)\end{array}$ & $\begin{array}{c}\lambda_{\min } \\
(\mathrm{m})\end{array}$ & $\begin{array}{c}\lambda_{\max } \\
(\mathrm{m})\end{array}$ & $\begin{array}{c}\mathrm{z}_{\min } \\
(\mathrm{m})\end{array}$ & $\begin{array}{c}\mathrm{z}_{\max } \\
(\mathrm{m})\end{array}$ \\
\hline $\mathrm{A} 1$ & $7,12.5,25$ & $2.9-11.6$ & $209-632$ & 19 & 219 & 6.4 & 110 \\
\hline $\mathrm{A} 2$ & $4,7.5,15$ & $5.3-15.6$ & $204-460$ & 13 & 87 & 4.4 & 43.5 \\
\hline A3 & $3,6,12$ & $12.4-40.1$ & $308-581$ & 7.8 & 46.8 & 2.6 & 23.4 \\
\hline A4 & $5,10,20$ & $7.9-22.5$ & $230-575$ & 10.24 & 72.7 & 3.4 & 36.4 \\
\hline
\end{tabular}




\subsubsection{Data processing}

Cross correlation between records on the circle and the central station were calculated in frequency domain to obtain the SPAC coefficient $\rho(f, R)$ (Aki 1957). Some examples of SPAC coefficients for different array radii are shown (Fig. 3).

$A 1, r=25 m$

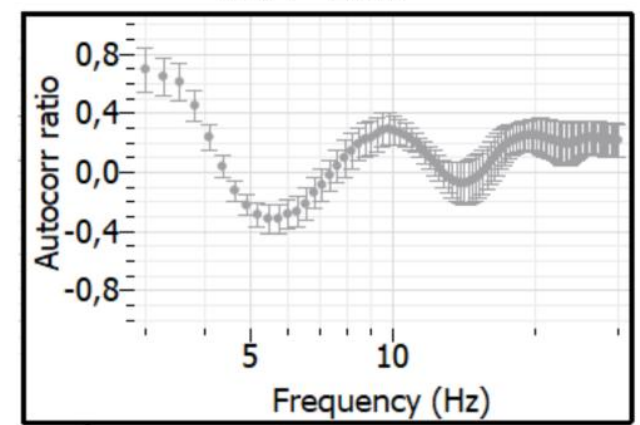

$A 2, r=15 m$

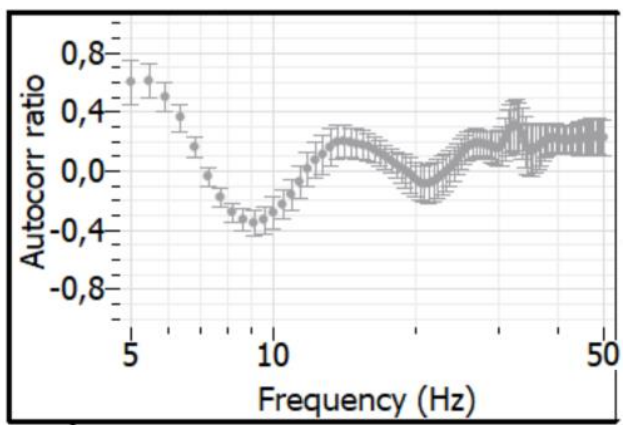

Fig. 3. Examples of SPAC curves obtained at arrays A1 and A2 for some array apertures.

Then, the phase-velocity of the Rayleigh wave, $c(f)$, was computed by using Geopsy software (Wathelet 2005) for each frequency from the equation:

$$
\rho(f, R)=J_{0}\left(\frac{2 \pi f}{\epsilon(f)} \cdot R\right)
$$

where, $J_{0}$ represents the zero-order Bessel function and $R$ is the radius of the array. All the solutions are represented in a $c$ vs. frequency diagram. Then, the dispersion curve corresponding to the fundamental mode of Rayleigh-waves is manually picked taking into account the aliasing limit for each ring (Fig. 4).

The HVSR of ambient computed at the array center were interpreted following the diffuse field approximation (Sánchez-Sesma et al. 2011). Under this approach, the power spectrum of motion at an arbitrary point $\mathbf{x}$ and along any Cartesian axis $m, P_{\mathrm{m}}(\mathbf{x}$; $\omega)$, is proportional to the imaginary part of the corresponding Green's function at the source, $\operatorname{Im}\left[G_{m m}(\mathbf{x}, \mathbf{x}, f)\right]$. Thus, the spectral ratio can be interpreted as:

$$
[H / V](\boldsymbol{x} ; \omega) \equiv \sqrt{\frac{2 P_{1}(x ; \omega)}{P_{g}\left(x_{j} \omega\right)}}=\sqrt{\frac{2 \operatorname{Im}\left[G_{11}\left(x ; x_{j} \omega\right)\right]}{\operatorname{Im}\left[G_{\mathrm{ga}}\left(x_{j} ; x_{j} \omega\right)\right]}} .
$$

The methods and algorithms for theoretical simulation and inversion of HVSRs described in García-Jerez et al. $(2013,2016)$ and implemented in hv-inv software were used to obtain 1D Vs models for each site from joint inversion of HVSRs and dispersion curves.

\subsection{MASW method}

About $3.5 \mathrm{~km}$ of linear transects were laid out through the streets of Adra (Fig. 1b) for MASW profiles. Location of these transects was chosen attending to the geological structures described by Alcalá et al. (2002). The MASW method was performed in both the active and passive modes (Park 1995). The combined use of active and passive forms of the MASW method allowed greater penetration depths and better resolutions of the Vs profiles (Park and Miller 2008). 

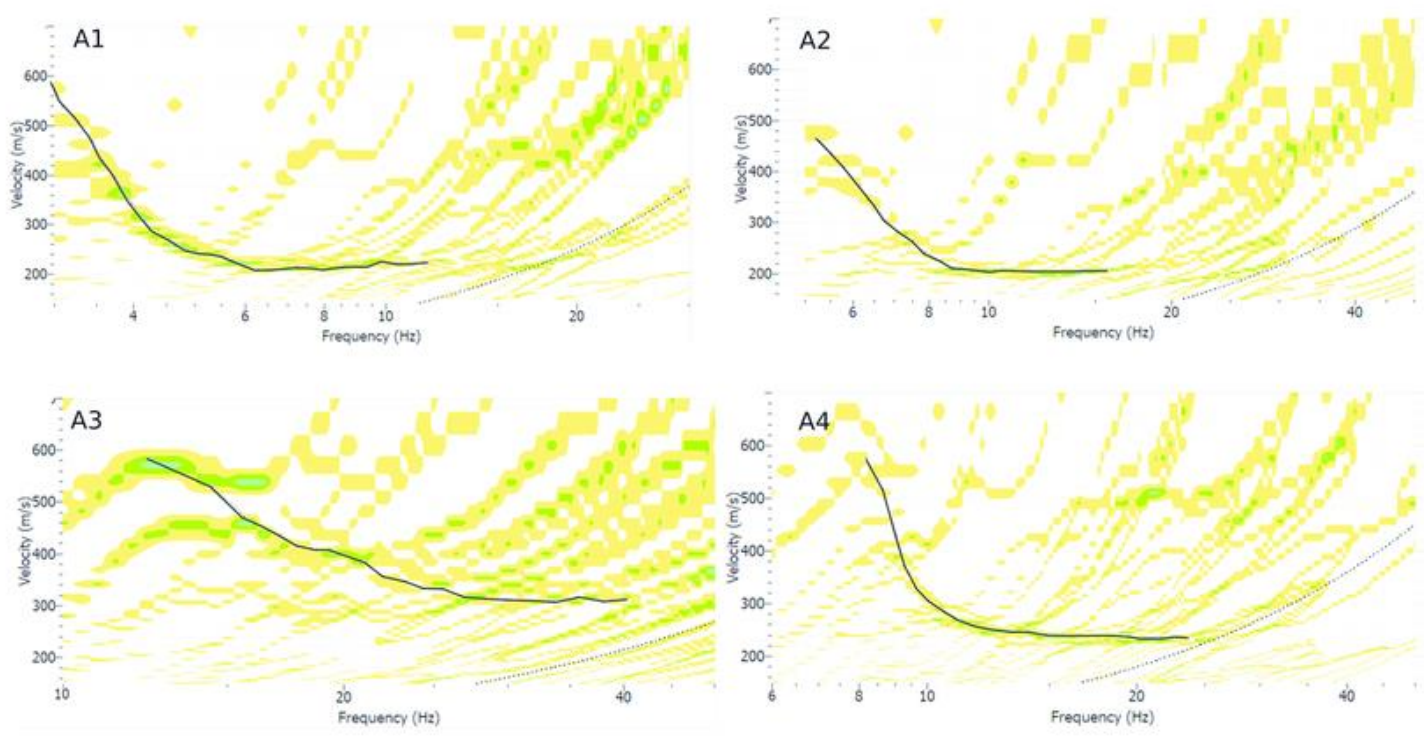

Fig. 4. Picking of dispersion curves from SPAC method. Green and blue cells indicate coincidence of solutions of Eq. (1) resulting from different radii. Black line shows the picked dispersion curve. The aliasing limit, computed as $\lambda_{\min }=1.8 r_{\text {min }}$, is shown with dotted line. The theoretical $\lambda_{\max }$ boundary would be outside the frequency-velocity range shown (lowest frequencies of the dispersion curves are determined by the data quality).

For active-mode MASW measurements, shallowest resolvable depth of investigation $\left(\mathrm{z}_{\min }\right)$ is approximately between $\lambda_{\min } / 3$ and $\lambda_{\min } / 2$, where $\lambda_{\min } \sim 2 * \Delta x$, being $\Delta \mathrm{x}$ the receiver spacing. The expected maximum investigation depth $\left(\mathrm{z}_{\max }\right)$ is approximately from $\lambda_{\max } / 3$ and $\lambda_{\max } / 2$, where $\lambda_{\max }$ corresponds in practice to the array length (Foti et al. 2017). Active surveys typically provide dispersion curves in a relatively high frequency (short wavelength) band (usually $20-50 \mathrm{~Hz}$ ).

A Wacker Neuson BS60-4s vibratory rammer was used in our measurements (Fig. 2c) in order to generate more powerful seismic source. To reach high productivity in terms of transect surveyed length per day, a towed land-streamer was built by using a heavy-duty fire hose (Fig. 2d), which enabled collecting data in a roll-along mode.

Passive Roadside MASW method has been implemented with a linear receiver array deployed along roadsides (Park and Miller 2008). Passive datasets were recorded for all the landstreamer positions (Fig. 1b). Recording time was $2 \mathrm{sec}$ and the signal was sampled with a rate of 500 sps. The measurements contain at least the passing of a vehicle during each recording. The estimated minimum investigation depth $\left(\mathrm{z}_{\mathrm{min}}\right)$ for this method is related to receiver spacing $(\Delta x): z_{\min }=m^{*} \Delta x$ with $1 / 3 \leq m \leq 1.0$ (http://www.masw.com/ACQ-PassiveRoadside.html). On the order hand, the maximum investigation depth $\left(\mathrm{z}_{\max }\right)$ is related to array dimension $(\mathrm{L}): \mathrm{z}_{\max }=\mathrm{L} / \mathrm{m}$, with $1.0 \leq \mathrm{m} \leq$ 3.0. The passive dataset may increase the maximum wavelength since lower frequencies are obtained from ambient noise, which allows increasing the explored depth. In general, passive surveys allow the measurements of the dispersion curve from low frequencies (typically $0.2-5 \mathrm{~Hz}$ ) to intermediate frequencies (around 10-30 Hz), depending, among other factors, on equipment, array geometry and array size (Foti et al. 2017).

A total of 24 geophones (12 of $28 \mathrm{~Hz}$ - and 12 of $4.5 \mathrm{~Hz}$ natural frequency) were interleaved and screwed onto metal plates with $2 \mathrm{~m}$ spacing. The offset (distance between the seismic source and the first geophone) was 4 meters. The acquisition array of $46 \mathrm{~m}$ in length was displaced 10 meters between consecutive shots using a small 
tractor (Fig. 2e). The recording unit was the SUMMIT II Compact unit from DMT, Germany.

\subsubsection{Data processing}

The SurfSeis software package from the Kansas Geological Survey, USA was used to process the seismic data. This software enabled us to retrieve a dense series of dispersion curves from which local 1D Vs models are obtained through an inversion process as in Park (2013) and Boiero et al. (2013). Dispersion curves of combined active and passive forms of the MASW method (Fig. 5) were manually picked from each shot gather after applying the wavefield transformation into the frequency-velocity domain described by Park et al. (1999). For each MASW profile, a 2-D MASW image was obtained integrating all 1-D Vs models following a standard procedure similar to the common-mid-point (CMP)-style data acquisition (Park et al. 1999; Xia et al. 1999). The 2-D MASW images are laterally continuous 2-D Vs cross-sections where the $\mathrm{X}$-axis is the horizontal location, $y$-axis is depth, and the colour scale bar represents the value of $\mathrm{Vs}$ in a discernible range.
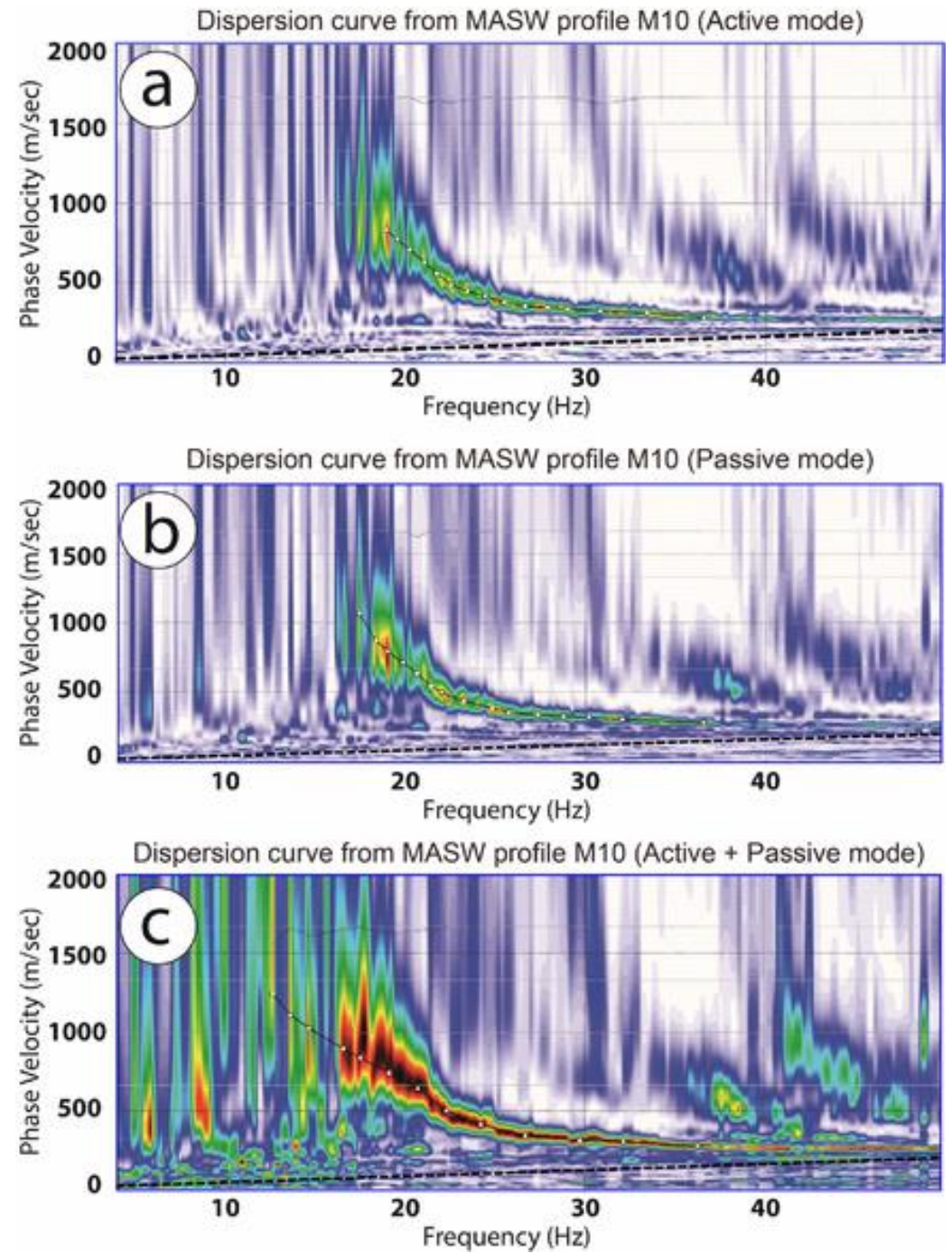

Fig. 5. Dispersion images from MASW M10 Profile. The white dots represent the dispersion picks that are further used for inversion in (a) mode active; (b) mode passive; and (c) mode active + passive. Dashed black lines correspond to the theoretical minimum wavelength for the array setup. 
MASW provides Vs information of ground materials by processing Rayleightype surface waves that are dispersive when travelling through a layered media. This dispersion property is determined from a material's Vs (by more than 95\%), P-wave velocity $(<3 \%)$, and density $(<2 \%)$. The accurate evaluation of the dispersion property is most important with any surface-wave method in this sense (Park 2013). Surfacewaves provide the highest possible signal-to-noise ratio (SNR) in any type of seismic approach. Consequently, the field operation for data acquisition and subsequent data analysis become extremely simple and effective, almost ensuring the most reliable results (Sairam et al. 2011; Park 2013; Yilmaz 2015). As an example of seismic quality data, Figure 6 depicts four dispersion curves combining the active and passive MASW methods in which the fundamental mode curves are clearly observable. Those fundamental mode curves were picked to generate a 2D Vs model by using the Xia et al. (1999) algorithm, based on a least-squares approach, inbuilt in SurfSeis. Finally, the 2D Vs models were averaged over the $30 \mathrm{~m}$ top to compute Vs30 (Park 2013) from the equation:

$$
V s 30=\frac{30}{\sum_{i=1}^{n} \frac{h_{i}}{v_{i}}},
$$

where $h_{i}$ and $v_{i}$ denote the thickness (in meters) and shear-wave velocity of the i-th layer, in a total of $\mathrm{n}$, existing in the top $30 \mathrm{~m}$.

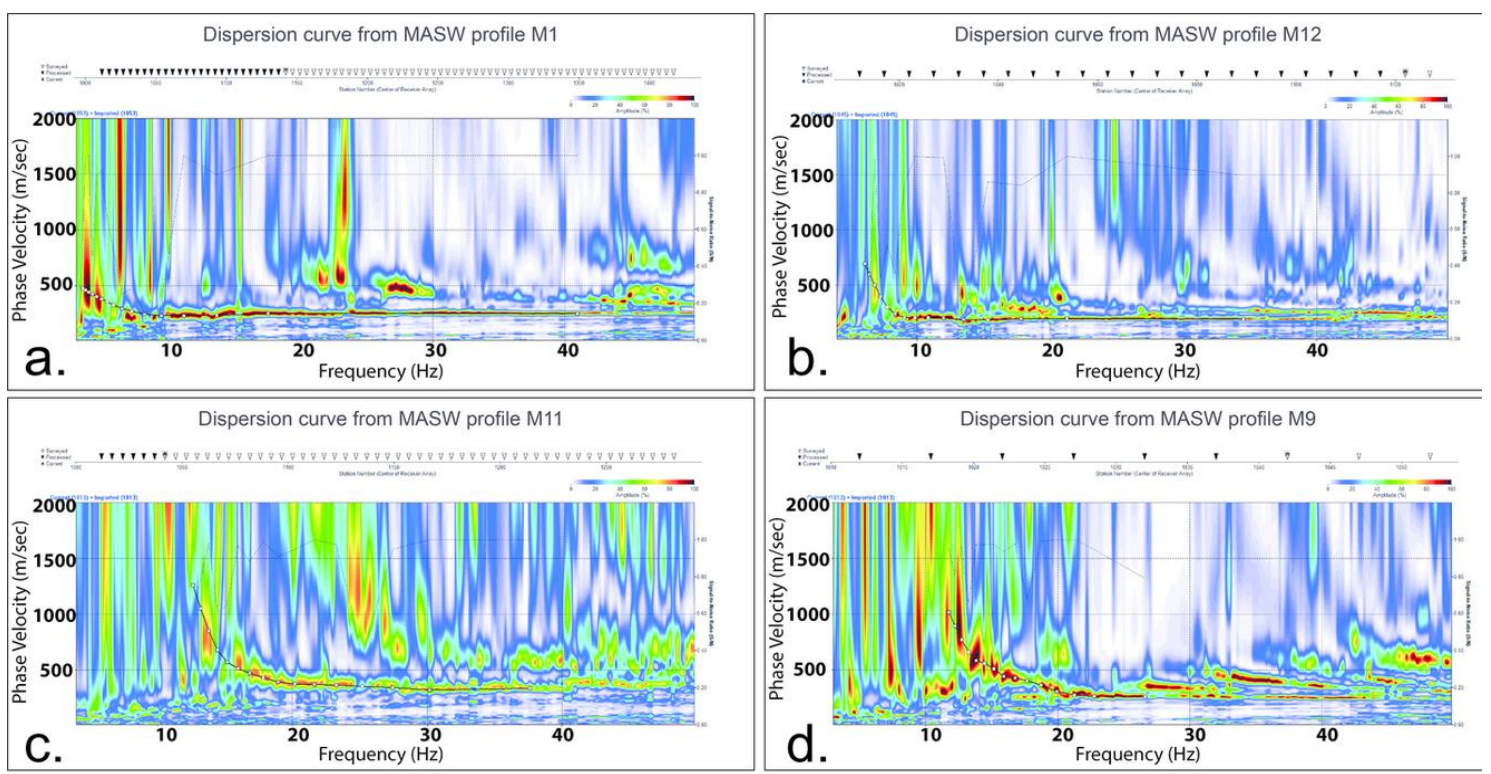

Fig. 6. Dispersion images from (a) MASW Profile M1; (b) MASW Profile M12; (c) MASW Profile M11; and (d) MASW Profile M9. The white dots represent the dispersion picks that are further used for inversion.

\section{Results}

Dispersion curves from SPAC measurements carried out in four open sites (Fig. 1b) show frequency range from 2.9 to $40.1 \mathrm{~Hz}$ and phase velocity values varied between 204 and 581 ms-1 (Table 2, Fig. 4). The maximum depth of investigation $\left(\mathrm{z}_{\max }\right)$, 
obtained from $\lambda_{\max }$, presents values ranging from $23.4 \mathrm{~m}$ (point A3) to $110 \mathrm{~m}$ (point A1). In all cases, the picked dispersion curves are within the theoretical wavelength range defined in section 3.1 and show a continuous shape, considering the reliable solutions generated by each radius.

Regarding MASW method, the depth of investigation $\left(\mathrm{Z}_{\max }\right)$ can be estimated from the maximum wavelength $\left(\lambda_{\max }\right)$ of the dispersion curves picked from combined active and passive images (Fig. 6). The frequency range is between 2.8 and $43.0 \mathrm{~Hz}$. Phase velocity values varied from 259 to $1198 \mathrm{~ms}^{-1}$ (Table 3, Fig. 4). The maximum wavelength shows values between 86 and $168 \mathrm{~m}$. Considering the $\mathrm{Z}_{\max }=\lambda_{\max } / 2$ approximation, the maximum depth of investigation varies from $43 \mathrm{~m}$ (point M9) to 84 $\mathrm{m}$ (point M1).

From active and passive MASW measurements, 341 1-D Vs profiles with depths greater than $30 \mathrm{~m}$ were calculated. These results allowed to obtain 13 2-D crosssections. Then, average Vs30 values have been computed (Table 4).

Table 3. Characteristics of the MASW array setup and dispersion curves at the array sites.

\begin{tabular}{|c|c|c|c|c|c|c|c|}
\hline MASW & $\begin{array}{c}\text { Length } \\
(\mathrm{m})\end{array}$ & $\begin{array}{c}\Delta \mathrm{f} \\
(\mathrm{Hz})\end{array}$ & $\begin{array}{c}\Delta \mathrm{c}_{\mathbb{R}} \\
\left(\mathrm{ms}^{-1}\right)\end{array}$ & $\begin{array}{c}\lambda_{\min } \\
(\mathrm{m})\end{array}$ & $\begin{array}{c}\lambda_{\max } \\
(\mathrm{m})\end{array}$ & $\begin{array}{c}\mathrm{z}_{\min } \\
(\mathrm{m})\end{array}$ & $\begin{array}{c}\mathrm{z}_{\max } \\
(\mathrm{m})\end{array}$ \\
\hline M1 & 810 & $2.8-43.0$ & $259-477$ & 6 & 168 & 2.0 & 84 \\
\hline M12 & 230 & $6.1-34.5$ & $183-690$ & 5.3 & 112 & 1.8 & 56 \\
\hline M11 & 540 & $12.9-37.6$ & $349-1198$ & 9 & 93 & 3 & 47 \\
\hline M9 & 80 & $11.7-36.2$ & $242-1010$ & 6.7 & 86 & 2.2 & 43 \\
\hline
\end{tabular}

Table 4. Average Vs30 values obtained from MASW profiles in Adra town.

\begin{tabular}{|c|c|c|c|c|}
\hline Profile & Street & $\begin{array}{c}\text { Length } \\
(\mathrm{m})\end{array}$ & $\begin{array}{c}\text { Vs30 range } \\
(\mathrm{m} / \mathrm{s})\end{array}$ & $\begin{array}{c}\text { Average } \\
\text { Vs30 } \\
(\mathrm{m} / \mathrm{s})\end{array}$ \\
\hline M1 & Ingenio & 810 & $296-482$ & 366 \\
\hline M2 & Paseo de Navegantes & 70 & $453-587$ & 486 \\
\hline M3 & Alcázar & 280 & $513-1046$ & 847 \\
\hline M4 & Unión & 240 & $523-778$ & 640 \\
\hline M5 & Camil de la Cuenca & 100 & $406-894$ & 567 \\
\hline M6 & Fenicios & 70 & $285-369$ & 340 \\
\hline M7 & Jumilla & 40 & $276-369$ & 320 \\
\hline M8 & Trafalgar F.C. & 530 & $287-509$ & 373 \\
\hline M9 & Bolivia & 80 & $346-517$ & 391 \\
\hline M10 & Fundición & 320 & $440-870$ & 655 \\
\hline M11 & Faro Alto & 540 & $441-1021$ & 604 \\
\hline M12 & $\begin{array}{c}\text { Marisma } \\
\text { (Recinto ferial) }\end{array}$ & 230 & $293-412$ & 349 \\
\hline M13 & Estero & 100 & $355-584$ & 414 \\
\hline
\end{tabular}

These low-frequency seismic data, together with the inversion of the HVSRs, constrain well the deeper layers (e.g. down to about 90 meters for the SPAC \#A1). Experimental dispersion curves and HVSRs, calculated at the array centres are compared with the simulated counterparts for the inverted models in Fig.7. 

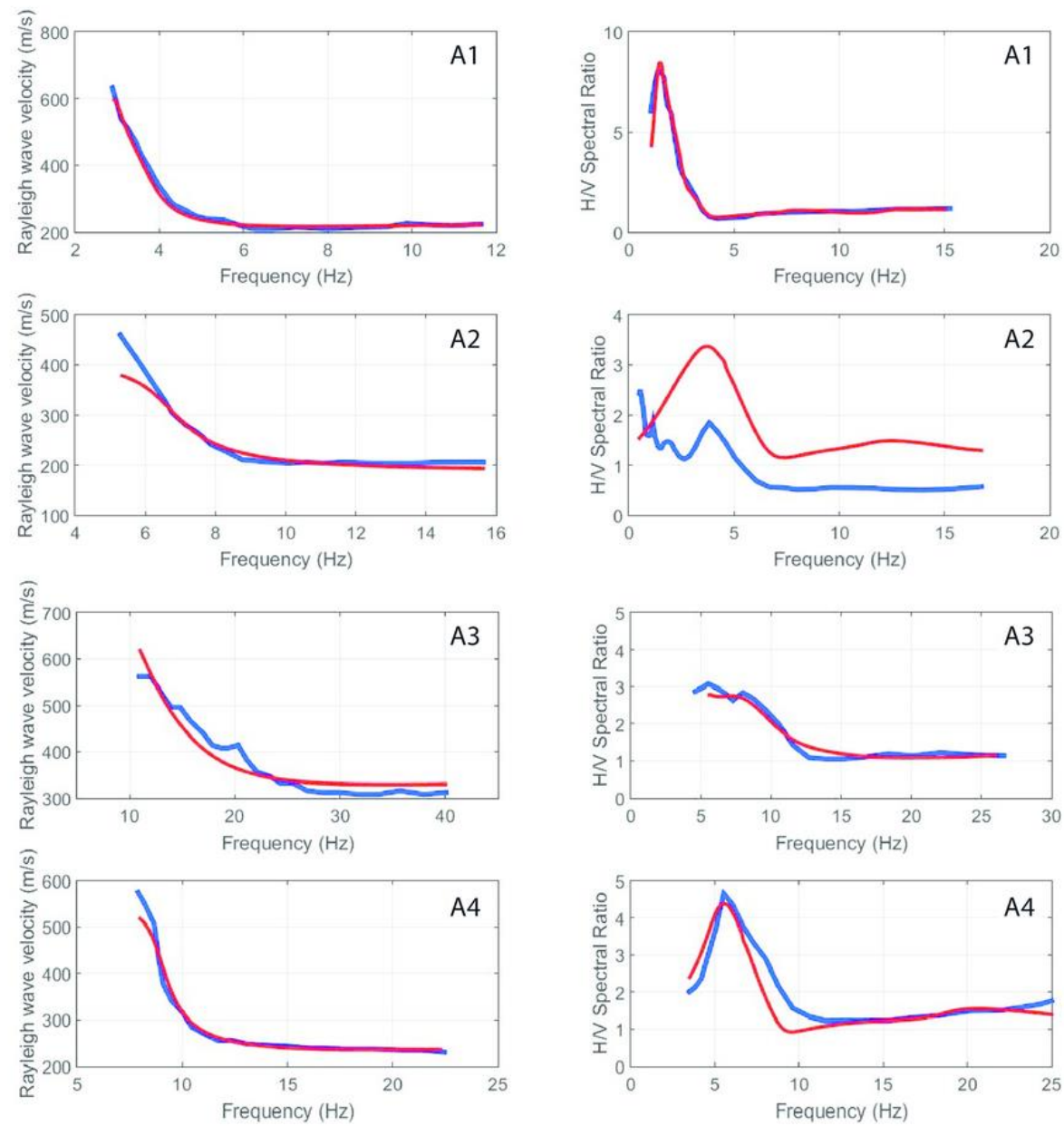

Fig. 7. Experimental dispersion curve (blue line) and theoretical dispersion curve (red line) for each SPAC point (left column); Experimental HVSR (blue line) and theoretical HVSR (red line) at each SPAC point (right column).

Both the SPAC method and the combination of the active- and passive-mode MASW processing described in the Methods section were able to gather reliable seismic information from the ground surface to $30 \mathrm{~m}$ depth (Fig. 8). However, the dispersion curves from MASW measurements exhibit a wider frequency range when compared to their SPAC counterparts. Hence, the analysed MASW frequency band ranged from minimum values comparable to those obtained with the SPAC method to frequencies above $30 \mathrm{~Hz}$, implying a better resolution of MASW seismic data into the first few meters depth (Park 2013).

The 1D Vs models provided by the two seismic methods show a similar patterns of material stiffness variation with depth. Some small shift could be observed in the comparison between these 1D Vs profiles, especially at the deepest horizons but even so, they were able to characterize the soil according to the Eurocode- 8 (EC8, 1998) classification with great agreement (Fig. 8). Table 5 summarizes this soil classification in terms of the Vs30 parameter and their geological correlation at each of those four measurement sites. 1D Vs models show the highest shift with depth among them, probably induced by geological heterogeneities, as deduced from borehole data described by Alcalá et al. (2002) and Ground Penetration Radar (GPR) profiles by Paz et al. (2017) (Fig. 8c). In any case, the shift of the 1D Vs models does not alter the agreement in terms of EC8 Class, characterizing the site as B1-type $(500-800 \mathrm{~m} / \mathrm{s})$. In 
fact, similar Vs30 values were obtained independently from SPAC $(569 \mathrm{~m} / \mathrm{s})$ and MASW $(580 \mathrm{~m} / \mathrm{s})$ methods, which agree well with Vs values found for similar lithologies in other urban areas in south-eastern Spain (Alcalá et al. 2002; García-Jerez et al. 2007; Navarro et al. 2007; 2014).

Table 5. Summary of the Vs30 values obtained from SPAC and MASW techniques and assigned soil-class classification according to the Eurocode-8 (EN 1998) standards.

\begin{tabular}{|c|c|c|c|c|c|c|}
\hline \multirow[t]{2}{*}{ SPAC ID (a) } & \multicolumn{2}{|c|}{ Geological-seismic Formations (b) } & \multirow[t]{2}{*}{ MASW ID (a) } & \multicolumn{2}{|c|}{ Average Vs $30, \mathrm{~m} \mathrm{~s}^{-1}$} & \multirow[t]{2}{*}{ EC8 (1998) classes } \\
\hline & Integrated formations & Age & & SPAC & MASW & \\
\hline \multirow[t]{3}{*}{ Al } & Adra river alluvial fan & Holocene & Ml & 270 & 322 & c \\
\hline & Shoreline facies & Holocene, Pleistocene & & & & \\
\hline & Shoreline facies & Pliocene & & & & \\
\hline \multirow[t]{3}{*}{ A2 } & Present marine terrace & Holocene & M12 & 310 & 326 & c \\
\hline & Colluvial fans & Holocene & & & & \\
\hline & Weathered Mica-schists & Palaeozoic & & & & \\
\hline \multirow[t]{3}{*}{$\mathrm{A} 3$} & Glacis II & Pleistocene & Mll & 569 & 580 & B1 \\
\hline & Marine terraces I & Pleistocene & & & & \\
\hline & Weathered Mica-schists & Palaeozoic & & & & \\
\hline \multirow[t]{3}{*}{ A4 } & Adra river alluvial fan & Holocene & M9 & 440 & 380 & B1 \\
\hline & Colluvial fans & Holocene & & & & \\
\hline & Shoreline facies & Pliocene & & & & \\
\hline
\end{tabular}

(a) ID and location of SPAC and MASW surveys as in Fig. 1b

(b) Geological and seismic deductions from Figs. 1c, 1d, 6a, 6b.
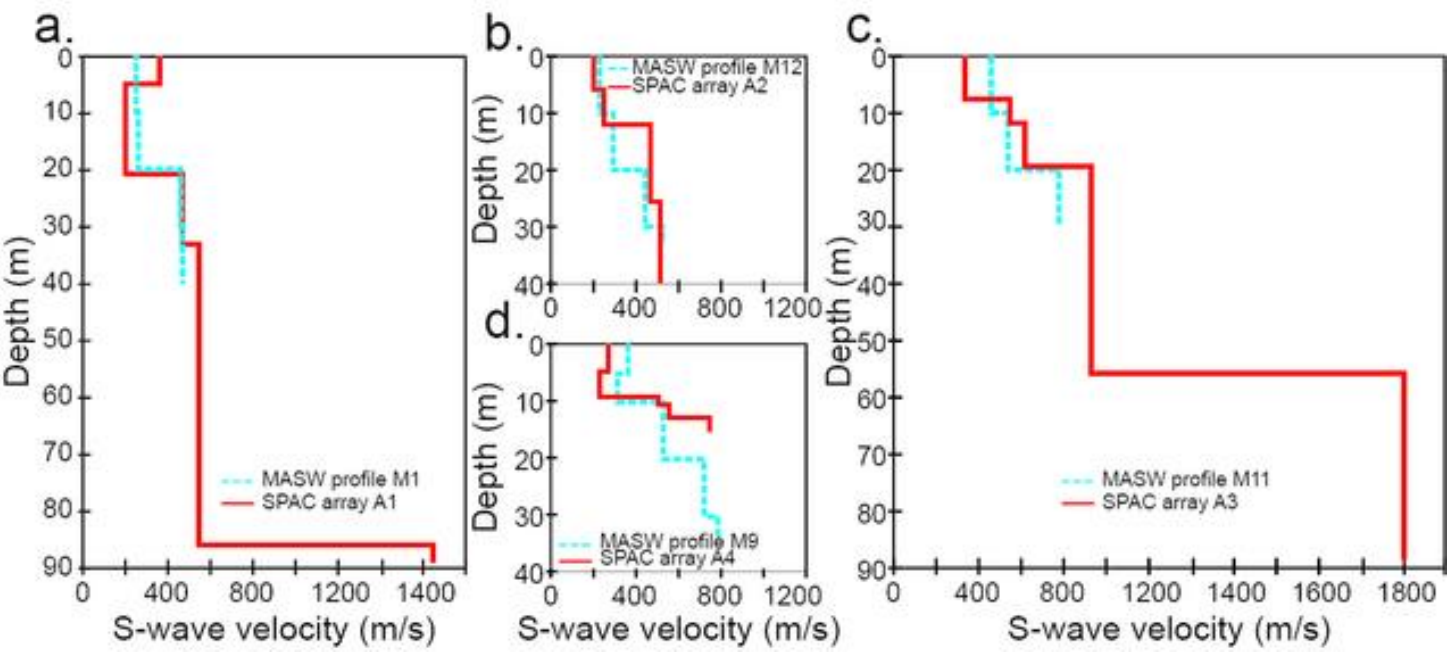

Fig. 8. 1-D Vs (m/s) best fitted models from (a) MASW Profile M1 and SPAC array A1; (b) MASW Profile M12 and SPAC array A2; (c) MASW Profile M11 and SPAC array A3; and (d) MASW Profile M9 and SPAC array A4.

For simplicity, only two representative MASW profiles (MASW profiles M1 and M10) are displayed in Fig. 9.

The MASW profile M1 shows the spatial variation of Vs up to $43 \mathrm{~m}$ depth. This profile was laid-out on a flat area of the town so that topographic correction was not required. The profile M1 exhibits a low velocity layer (LVL) in the uppermost $10 \mathrm{~m}$ characterized by a relatively sharp transition boundary of velocities below $450 \mathrm{~m} / \mathrm{s}$, which is thicker than the observed in the northernmost sector (Fig. 9b). 


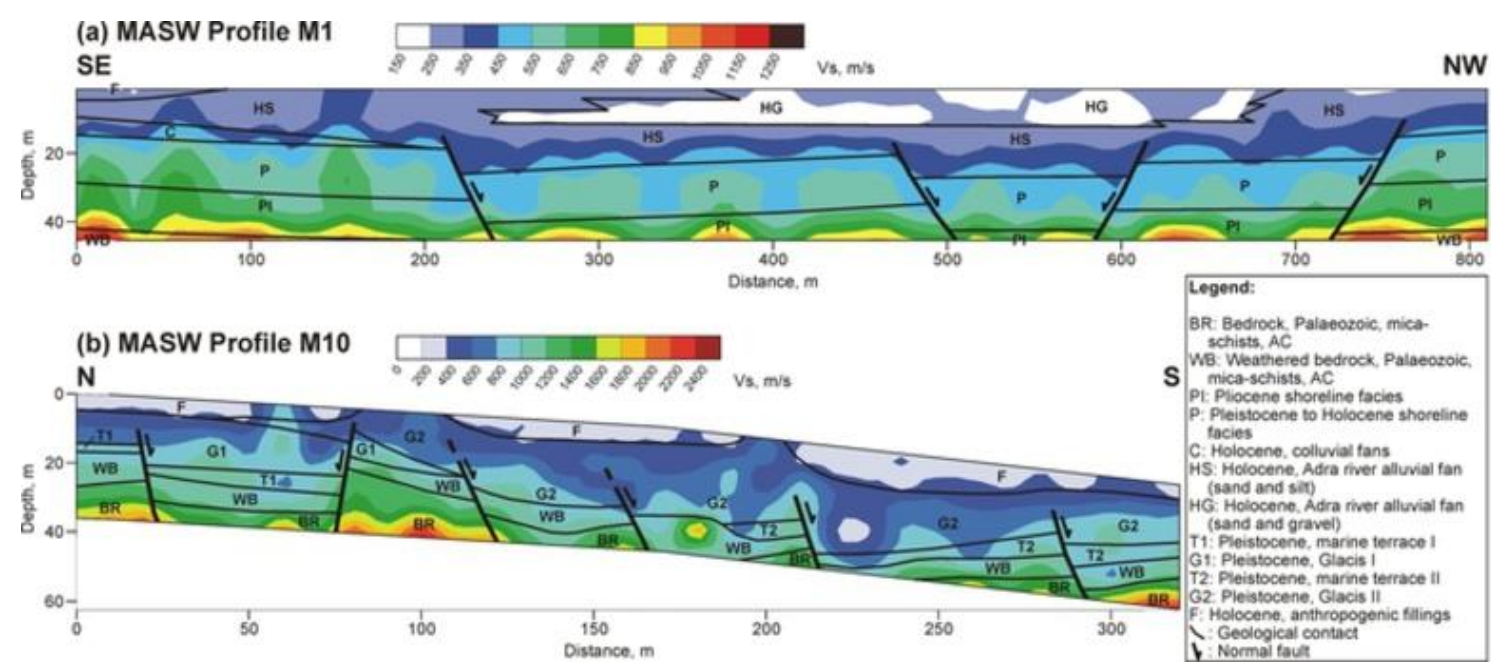

Fig. 9. 2D Vs (m/s) models for MASW Profiles M1 (a) and M10 (b) with existing geological information (for shallower meters) and deduced geological features after surveying (for deeper meters) overimposed; location of profiles as in Fig. 1b. AC: Alpujárride Complex.

\section{Discussion}

Detailed geological information inferred from the 1:5,000 scale geological crosssections I-I' and II-II' (Fig. 1d) was superimposed on the 2D Vs models for MASW profiles M1 and M10 (Fig. 9). According to the geological information, the LVL in M1 corresponds to low-diagenetic (soft) Holocene deposits, mostly sand and silt from the Adra river alluvial fan. Some pockets with Vs values below $250 \mathrm{~m} / \mathrm{s}$ are embedded into an upper low-velocity layer (coloured white in Figure 9a), which correspond to a gravel-rich sandy alluvial deposit, as corroborated from GPR surveys (Paz et al. 2017). The LVL overlays a medium velocity layer (MVL) with Vs values in the $450-650 \mathrm{~m} / \mathrm{s}$ range associated to Pleistocene glacis with a thickness slightly above 10 meters. Underlying this medium velocity layer, a third layer attributed to Pliocene materials with different elastic properties determines the increase of Vs above $950 \mathrm{~m} / \mathrm{s}$. At the lower left corner of the profile, the highest Vs values (>1000 m/s), are attributed to the weathered Palaeozoic schist bedrock, as deduced from direct observations, borehole data, and GPR surveying (Alcalá et al. 2002; Navarro et al. 2007; Paz et al. 2017). This interpretation of the bed-rock location is well supported because similar Vs values have been found in other seismic cross-sections at a similar depth with checkable presence of Palaeozoic schist. The M1 Vs profile increases understanding of subsoil characteristics and improves the in-depth position of some expected normal faults described by Alcalá et al. (2002) and finely defined in its shallowest tract by Paz et al. (2017). This normal fault occurrence explains well some slight shift observed when following the Pleistocene and Holocene boundary (Fig. 9a). In general, Vs values of MASW profile M1 identifies the poor subsurface mechanical properties of the geological materials described in that sector and supported by Alcalá et al. (2002) and Navarro et al. (2007).

The M10 profile shows the influence of geological materials with better elastic properties in terms of Vs. With Vs above $1000 \mathrm{~m} / \mathrm{s}$, the Palaeozoic schist hard rock appears shallower on the right-hand side of profile. The presence of shallowest Palaeozoic schist displaying better surface mechanical properties in terms of seismic 
amplification justify why no building damage was reported in northern sector of the town during the 1993 and 1994 earthquakes. The thickness of layers assigned to Pleistocene glacis II (G2), which is characterized by Vs values in the $400-500 \mathrm{~m} / \mathrm{s}$ range, tends to decrease northward. The Pleistocene glacis I (G1) underlying the G2 has been mapped in the north of the town. G1 provides Vs values in the 400-600 m/s range as shown at the top on the left-hand side of the profile in Figure 9b. According to geological data the Pleistocene terraces I (T1) and II (T2) underlying G1 and G2 could be characterized in terms of Vs, varying T1 in the 500-800 m/s range and T2 in the 450$600 \mathrm{~m} / \mathrm{s}$ range, respectively. Based on the geological information a set of small faults whose occurrence explains the abrupt lateral Vs changes have been drawn. The MASW profiles in general and this M10 profile in particular have helped to delineate other additional minor faults.

Velocity boundaries at $180,360,500$, and $800 \mathrm{~m} / \mathrm{s}$ in Vs30, taken from the Eurocode 8 (1998) soil classes, were adopted to represent the shallow shear velocity structure of Adra, following other works such as Navarro et al. $(2008,2014)$ and Martínez-Pagán et al. (2014). Our findings show that the continental glacis overlying the Palaeozoic hard rocks at the northernmost sector of the town produce Vs30 values above $800 \mathrm{~m} / \mathrm{s}$, qualifying that area as EC8 Class A-type. H/V measurements carried out by Navarro et al. (2007) showed the lowest soil predominant periods (0.10 to $0.30 \mathrm{~s})$ at that sector, as result of the higher mean velocities (apart from a shallowest soft layer of $4-5 \mathrm{~m}$ ) of the hard rock which give the best mechanical condition in terms of site amplification (Yilmaz 2015) in Adra town. It is noteworthy that buildings did not suffer any damage in that sector. Adjacent to the northernmost sector and with similar seismic characteristics spreads, the northwest sector of the town reflected Vs30 in the 500-800 $\mathrm{m} / \mathrm{s}$ range within the EC8 Class B1-type. This Vs30 range correlate well with the presence of Pleistocene glacis in that sector. Nevertheless, some significant building damage occurred in specific locations in the eastern sector of the town where the soft Holocene Adra river alluvial fan and some colluvial fans outcrop. Kanli et al. (2006) showed that the usefulness of Vs distribution maps for different depths in earthquake hazard studies: the presence of softer materials in the first few meters depth may influence the building damage probability level. It is important to note that Navarro et al. (2007) demonstrated the occurrence of visible microtremor resonant phenomena in that sector of the town since soils with predominant periods around $0.20 \mathrm{~s}$ coexisted with four-storey buildings having the same period. Some of them were severely damaged during the Adra 1993-1994 earthquake sequence (Fig. 10). The analysis of microtremor measurements is a quick, easy and inexpensive way to assess the dynamic behaviour of building structures based on the fact that microtremor spreads on the building structure and is amplified at soil predominant periods close to the natural period of the building (Panzera et al. 2016). Another important point is the main building damage distribution zone located in the transition among the G2, classified as EC8 Class B1-type, and the Holocene Adra river alluvial fan and colluvials fans, classified as EC8 Class C-type (180-360 m/s). This transition area is characterized by Vs30 values in the $360-500 \mathrm{~m} / \mathrm{s}$ range within the EC8 site Class B2. Additionally, the hard rock in this transition area is affected by a huge density of conjugated small faults, (Paz et al. 2017), which may tend to decrease their mechanical properties.

From the transition area to the southern sector of the town, the thickness of Holocene formations increases progressively, involving Vs30 values from 180 to 360 $\mathrm{m} / \mathrm{s}$ consistent with EC8 Class C soils. These values suggest possible shaking 
amplifications during an earthquake due to weaker soil characteristics. Indeed, these soft alluvial and colluvial materials are covered by recent anthropogenic unconsolidated fillings in specific locations (Alcalá et al. 2002; Paz et al. 2017) (Figs. 1c and 1d). In addition, the increasing depth of the soft sediment-bedrock boundary towards the southeastern sector of the town determines the increasing of predominant periods (greater than $0.5 \mathrm{~s}$ ), highlighting that this sector of the town is highly prone to seismic amplification of the low-frequency spectral components (Fig. 10). Since that sector had not yet been urbanized, no building damage was reported there during the Adra 1993, 1994 earthquake sequence. However, these findings should be taken into account by the municipality of Adra, because the town is currently growing towards that sector.

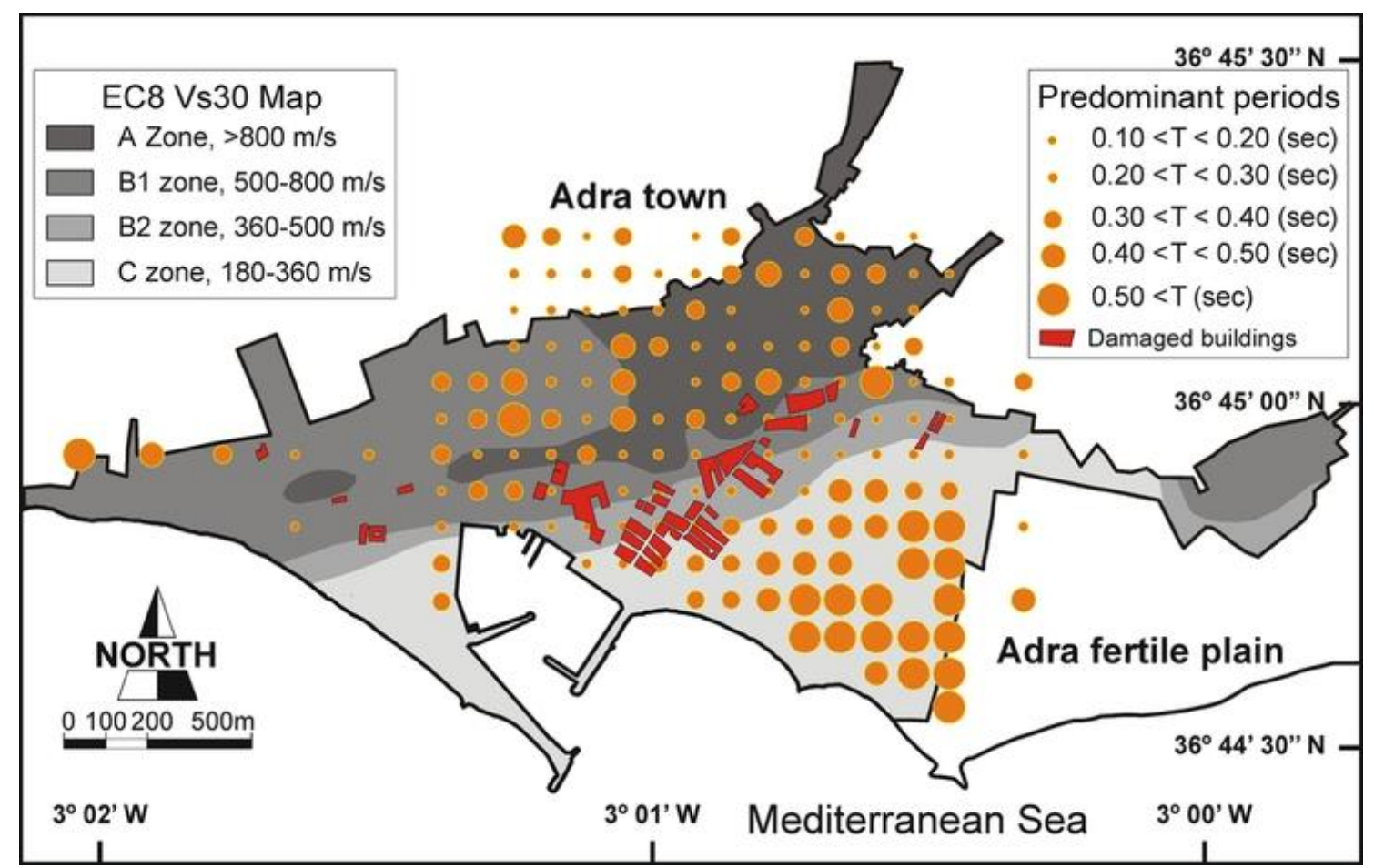

Fig. 10. Average Vs30 (m/s) map Adra town following the Eurocode-8 (EN 1998) criteria, with the overimposed distributions of soil predominant periods (s) and damaged buildings after the 1993 and 1994 Adra earthquakes, both modified from Navarro et al. (2007).

Following similar studies (Kanli et al. 2006), we propose an alternative 2D representation of the Vs profiles to show the average shear-wave velocity distribution at different depths $(5,10,15,20,25$, and $30 \mathrm{~m})$, following increments of $150 \mathrm{~m} / \mathrm{s}$ (Fig. 11). Interestingly, average Vs down to $5 \mathrm{~m}$ depth (Vs05) shows that almost all the damaged buildings fall into the 150-450 m/s range. Nevertheless, we observe that these damaged buildings still fall into the zone with Vs20 from $150 \mathrm{~m} / \mathrm{s}$ to $450 \mathrm{~m} / \mathrm{s}$. This can be explained because normal faults increase up to $20 \mathrm{~m}$ the thick of soft sediments in this sector (Fig. 1d). It is relevant to note that few damaged buildings fall into zones with average Vs above $600 \mathrm{~m} / \mathrm{s}$ (even for Vs05). In general, the Vs zones correlate well with boundaries and thicknesses of recognized geological formations and faults. This feature allows to propose the geology of the town as a basic supporting data for predictable Vs. 


\section{Conclusions}

This study compares independent dataset obtained through MASW and SPAC methods to perform reliable seismic microzonation studies of assistance for seismic hazard management in urban areas. The combination of these two seismic methods allows compiling a huge amount of shallow Vs data, which represented valuable information to perform a detailed microzonation map of Adra town. The existing detailed geology was a key piece of information to support the interpretations.

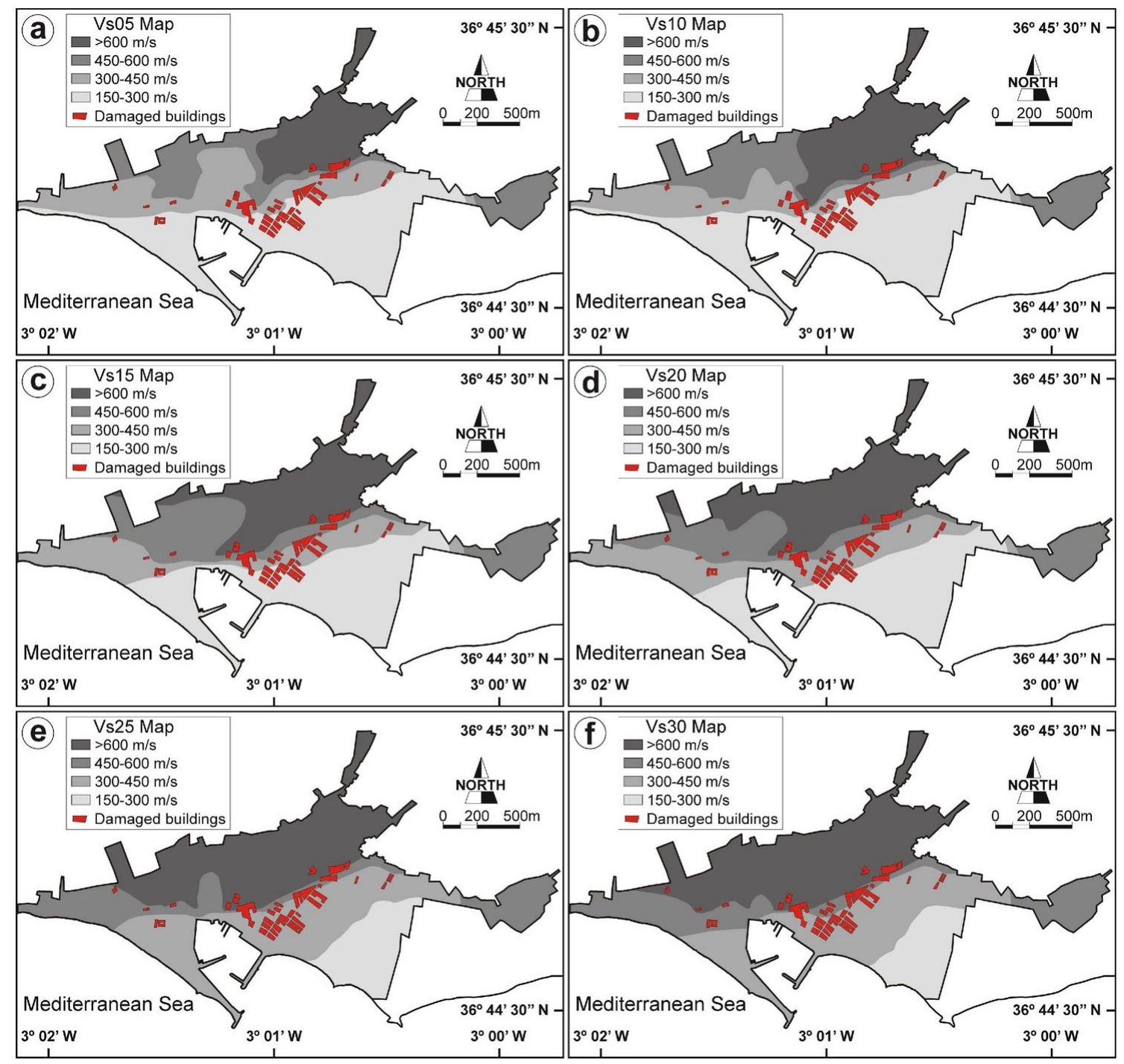

Fig. 11. Average Vs30 (m/s) distribution maps of Adra town down to (a) $5 \mathrm{~m}$ depth; (b) $10 \mathrm{~m}$ depth; (c) $15 \mathrm{~m}$ depth; (d) $20 \mathrm{~m}$ depth; (e) $25 \mathrm{~m}$ depth; and (f) $30 \mathrm{~m}$ depth. Damaged buildings after the 1993 and 1994 Adra earthquakes are overimposed.

Results from SPAC and HVSRs analysis under the diffuse field approximation, and those from active and passive MASW surveys in coincident sites provided similar Vs30 models, leading to similar soil-type classifications in terms of Eurocode 8 (EN 1998). The joint application of these methods allows a suitable cross-checking of data as a prerequisite to provide accurate results. Four SPAC arrays located into the 
trajectories of four MASW profiles were conducted for accurate 1D Vs models used for cross-checking.

Turning to the MASW method, the land-streamer system proved to be a useful tool for gathering a huge amount of seismic data from the ground surface to $30 \mathrm{~m}$ depth. This capability enabled a more exhaustive and consistent soil classification of Adra town following EC8 criteria. The MASW method was a suitable method to detail the geological changes induced by fault systems previously identified in surface, which determine the different magnitude of Vs recorded at short distances in some sites. Note that this is an ongoing study so information from new geotechnical boreholes could be added to improve the interpretation of $2 \mathrm{D}$ Vs models deduced from existing MASW profiles. Nevertheless, the 2D Vs models were consistent with the existing geological information. The seismic site classification map for Adra town showed the best soil properties at northern sectors, corresponding to EC8 site Class A; this was expected because the Palaeozoic schist bed-rock is shallower or outcropping and no damage was reported in the 1993-1994 Adra earthquakes sequence in this sector. On the contrary, significant building damage occurred in EC8 B1-type sectors composed of Holocene Adra river alluvial fan in which resonant phenomena were evidenced from previous microtremor records. Most of building damages took place in a transition area characterized as Site Class B2, which corresponds to Holocene Adra river alluvial fan and colluvial fans of increasing thickness towards the southern sector of the town. This area has been classified as EC8 Class C-type. Larger predominant periods (greater than $0.5 \mathrm{~s}$ ) were found in this zone, which is highly prone to shaking amplification during an earthquake and resultant liquefaction.

The detailed soil characteristic maps based on the Vs distribution is useful for site safety evaluation studies addressed to future urban planning. It is important to highlight that proper structural designs and construction practices should be conducted as Adra town expands toward the southeastern sector.

\section{Acknowledgements}

Research funded by the Spanish CICYT Research Projects CGL2011-30187C02-02 and CGL2014-59908 supported by ERDF, and the Seneca Foundation Research Project 15322/PI/10. The authors gratefully acknowledge the support provided by the Civil Defense and the Police Staffs of Adra. The authors wish to express their sincere gratitude to Gerson Ramos da Silva for his support during the field measurements and to Carole and John Moor for improving the English language of the manuscript. The authors would like to thank the successful comments made by the reviewers and Beatriz Benjumea, which has contributed to the improvement of the quality of the article

\section{References}

Aki K. 1957. Space and time spectra of stationary stochastic waves, with special reference to microtremors. Bulletin of the Earthquake Research Institute, 35, 415456.

Alcalá F.J., Espinosa J., Navarro M. and Sánchez F.J. 2002. Proposal of a geological division of Adra town (Province of Almeria). Application to seismic microzonation. Revista de la Sociedad Geológica de España, 15 (1-2), 55-66 (in Spanish with abstract in English). 
Alcalá F.J., Guerrera F., Martín-Martín M., Raffaelli G. and Serrano F. 2013. Geodiynamic implications derived from Numidian-like distal turbidites deposited along the Internal-External Domain Boundary of the Betic Cordillera (S, Spain). Terra Nova, 25 (2), 119-129.

Aldaya F., Baena J. and Ewert K. 1983. Spain Geologic Map, 1:50000, sheet no. 1.057 (Adra). IGME, Madrid (in Spanish).

Benito B., Navarro M., Murphy P., Vidal F., Gaspar-Escribano J., Jiménez M.E. and García M.J. 2007. Riesgo sísmico en Andalucía. Proyecto SISMOSAN, V1, V2, V3, V4. UPM, Madrid (in Spanish).

Boiero D., Socco L.V., Stocco S. and Wisén R. 2013. Bedrock mapping in shallow environmental using surface-wave analysis. The Leading Edge, 32 (6), 664-672.

Burke R.W. and Schofield N.B. 2008. The multichannel analysis of surface waves (MASW) method as a tool for ground improvement certification. Proceedings of the Symposium on the Application of Geophysics to Engineering and Environmental Problems, 1041-1055.

Carnevale M., Hager J., Brinkmann J.W. and Jones B.R. 2005. MASW and GPR survey to delineate depth to bedrock and crystal cavities for mineral exploration, Hiddenite, North Carolina. Proceedings of the Symposium on the Application of Geophysics to Engineering and Environmental Problems, 1051.1060.

Chang W.J., Ni S.H., Huang A.B., Huang Y.H. and Yang Y.Z. 2011. Geotechnical reconnaissance and liquefaction analyses of a liquefaction site with silty fine sand in Southern Taiwan. Engineering Geology, 123, 235-245.

Duffy B., Campbell J., Finemore M. and Gomez C. 2014. Defining fault avoidance zones and associated geotechnical properties using MASW: A case study on the Springfield fault, New Zealand. Engineering Geology, doi: 10.1016/j.enggeo.2014.10.017.

Eker A.M., Akgün H. and Koçkar M.K. 2012. Local site characterization and seismic zonation study by utilizing active and passive surface wave methods: A case study for the northern side of Ankara, Turkey. Engineering Geology, 151, 64-81.

EN. 1998. Eurocode No. 8. Design of structures for earthquake resistance. Commission of the European Communities. Doc CEN/TC250/SC8/N335.

Foti S., Hollender F., Garofalo F., Albarelo D., Asten M., Bard P-Y., Comina C., Cornou C., Cox B., Di Giulio G., Forbriger T., Hayashi K., Lunedei E., Martin A., Mercerat D., Ohrnberger M., Poggi V., Renalier F., Sicilia D., Socco V. 2017. Guidelines for the good practice of Surface wave analysis: a product of the InterPACIFIC Project. Bulletin of Earthquake Engineering. DOI 10.1007/s10518017-0206-7.

García-Jerez A., Navarro M., Alcalá F.J., Luzón F., Pérez-Ruíz J.A., Enomoto T., Vidal F. and Ocaña E. 2007. Shallow velocity structure using joint inversion of array and H/V spectral ratio of ambient noise: the case of Mula town (SE of Spain). Soil Dynamics and Earthquake Engineering 27, 907-919.

García-Jerez A., Luzón F., Navarro M. and Pérez-Ruiz J.A. 2008a. Determination of elastic properties of shallow sedimentary deposits applying a spatial autocorrelation method. Geomorphology 93, 74-88.

García-Jerez A., Luzón F. and Navarro M. 2008b. An alternative method for calculation of Rayleigh and Love wave phase velocities by using three-component records on a single circular array without a central station. Geophys. J. Int. 173, 844-858. 
García-Jerez A., Luzón F., Navarro M. and Santoyo M.A. 2010. Assessing the Reliability of the Single Circular Array Method for Love-Wave Ambient Noise Surveying. Bulletin of the Seismological Society of America 100, 2230-2249.

García-Jerez A., Luzón F., Sánchez-Sesma F.J., Lunedei E., Albarello D., Santoyo M.A. and Almendros J., 2013. Diffuse elastic wavefield within a simple crustal model. Some consequences for low and high frequencies. J. Geophys. Res. Solid Earth 118, 5577-5595.

García-Jerez A., Piña-Flores J., Sánchez-Sesma F.J., Luzón F. and Perton M. 2016. A computer code for forward calculation and inversion of the $\mathrm{H} / \mathrm{V}$ spectral ratio under the diffuse field assumption. Comput. Geosci. 97, 67-78.

Goy J.L. and Zazo C. 1986. Synthesis of the Quaternary in the Almeria litoral, neotectonic activity and its morphologic features (eastern Betics, Spain). Tectonophysics, 130, 259-270.

Imai T. 1981. P- and S-wave velocities of the ground in Japan. Proceedings of the $9^{\text {th }}$ International Conference of Soil Mechanics and Foundation Engineering, Tokyo, vol. 2, 215-240.

INE. 2017. Spanish National Institute for Statistics. Cifras Oficiales de Población de los Municipios Españoles: Revisión del Padrón Municipal - Población a 1 de enero de 2017 (in Spanish).

Ivanov J., Miller R.D., Stimac N., Ballard Jr. R.F., Dunbar J.D. and Smullen S. 2006. Time-lapse seismic study of levees in southern New Mexico. $76^{\text {th }}$ Annual International Meeting, SEG, Expanded Abstracts, 3255-3259.

Kanli A.I., Tildy P., Prónay Z., Pinar A. and Hermann L. 2006. Vs30 mapping and soil classification for seismic site effect evaluation in Dinar region, SW Turkey. Geophysical Journal International, 165, 223-235.

Kokusho T. 1987. In-situ dynamic soil properties and their evaluation. Proceedings of the $8^{\text {th }}$ Asian Regional Conference of Soil Mechanics and Foundation Engineering, Kyoto, vol. 2, 215-240.

Kolat C., Ulusay R. and Suzen M.L. 2012. Development of geotechnical microzonation model for Yenisehir (Bursa, Turkey) located at a seismically active region. Engineering Geology, 127, 36-53.

Lorenzo J.M., Hicks J. and Vera E.E. 2014. Integrated seismic and cone penetration test observations at a distressed earthen levee: Marrero, Louisiana, U.S.A. Engineering Geology, 168, 59-68.

Mahajan A.K. 2009. NEHRP soil classification and estimation of 1-D site effect of Dehradun fan deposits using shear wave velocity. Engineering Geology, 104, 232240.

Martínez-Pagán P., Navarro M., Pérez-Cuevas J., García-Jerez A. and SandovalCastaño S. 2014. Shear-wave velocity based seismic microzonation of Lorca city (SE Spain) from MASW analysis. Near Surface Geophysics, 12, doi:10.3997/18730604.2014032.

Miller R., Xia J. and Park C.B. 1999. MASW to investigate subsidence in the Tampa, Florida area. Kansas Geological Survey Open-file Report No. 99-33.

Nakamura 1989. A method for dynamic characteristics estimation of subsurface using microtremors on the ground surface. Quaterly Report of Railway Technical Research Institute, 30, 25-33. 
Navarro M., Alcalá F.J., Vidal F., Enomoto T., Abeki, N. and Sánchez F.J. 2002. Evaluation of Site Effects in Adra Town (southern Spain). Física de la Tierra, 14, 215-228.

Navarro M., García-Jerez A., Alcalá F.J., Vidal F., Enomoto T., Luzón F. and Creus C. 2008. Vs30 Structure of Lorca town (SE Spain) from ambient noise array observations. $31^{\text {st }}$ General Assembly of the European Seismological Commission (ESC 2008), Hersonissos, (Crete, Greece), 7-12 September.

Navarro M., Vidal F., Enomoto T., Alcalá F.J., García-Jerez A., Sánchez F.J. and Abeki N. 2007. Analysis of the weightiness of site effects on reinforced concrete (RC) building seismic behavior. The Adra town example (SE Spain): Earthquake Engineering and Structural Dynamics, 36, 1363-1383.

Navarro M., García-Jerez A., Alcalá F.J., Vidal F. and Enomoto T. 2014. Local site effect microzonation of Lorca town (SE Spain). Bulletin of Earthquake Engineering, 12:1933-1959.

NEHRP. Building Seismic Safety Council. 2001. National Earthquake Hazards, Reduction Program (NEHRP) Recommended Provisions for Seismic Regulations for New Buildings and Other Structures, Part 1 - Provisions and Part 2 Commentary, Reports No. FEMA-368 and FEMA-369, prepared by the Building Seismic Safety Council for the Federal Emergency Management Agency, Washington, D.C.

Olona J., Pulgar J.A., Fernández-Viejo G., López-Fernández C. and González-Cortina J.M. 2010. Weathering variations in a granitic massif and related geotechnical properties through seismic and electrical resistivity methods. Near Surface Geophysics, 8, 585-599.

Panzera F. D'Amico S. Lombardo G. and Longo E. 2016. Evaluation of building fundamental periods and effects of local geology on ground motion parameters in the Siracusa área, Italy. Journal of Seismology, 20, 1001-1019.

Panzera F. and Lombardo G. 2013. Seismic property characterization of lithotypes cropping out in the Siracusa urban area, Italy. Engineering Geology, 153, 12-24.

Park C.B. 2013. MASW for geotechnical site investigation. The Leading Edge, 32 (6), 656-662.

Park C.B. 1995. Characterization of geotechnical sites by Multichannel Analysis of Surface Wave. Proceeding of the Korean Ground Society, 95th annual meeting: Seoul, Korea, 15-21.

Park C.B., Miller R.D. and Xia J. 1999. Multi-channel analysis of surface waves (MASW). Geophysics, 63, 800-808.

Park C.B. and Miller R.D. 2008. Roadside passive Multichannel Analysis of Surface Wave (MASW). Journal of Environmental and Engineering Geophysics, 13(1), 111.

Paz C., Alcalá F.J., Carvalho J.M. and Ribeiro L. 2017. Current uses of ground penetrating radar in groundwater-dependent ecosystems research. Science of the Total Environment, 595, 868-885.

Sairam B., Rastogi B.K., Aggarwal S., Chauhan M. and Bhonde U. 2011. Seismic site characterization using Vs30 and site amplification in Gandhinagar region, Gujarat, India. Current Science, 100 (5), 754-761.

Sánchez-Sesma F.J., Rodríguez M., Iturrarán-Viveros U., Luzón F., Campillo M., Margerin L., García-Jerez A., Suarez M., Santoyo M.A. and Rodríguez-Castellanos 
A. 2011. A theory for microtremor $\mathrm{H} / \mathrm{V}$ spectral ratio: application for a layered medium. Geophys. J. Int. 186, 221-225.

Sanz de Galdeano C. 1997. The Betic Rift Internal Zone. University of Granada, 316 pp (in Spanish with abstract in English).

Sanz de Galdeano C., López Casado C., Delgado J. and Peinado M.A. 1995. Shallow seismicity and active faults in the Betic Cordillera. A preliminary approach to seismic sources associated with specific faults. Tectonophysics, 248, 293-302.

SESAME. 2005. Guidelines for the Implementation of the H/V Spectral Ratio Technique on Ambient Vibrations: Measurements, Processing and Interpretation. SESAME European Research Project / WP12 - Deliverable D23.12, European Commission - Research General Directorate Project No. EVG1-CT-2000-00026.

Suto K. 2013. MASW surveys in landfill sites in Australia. The Leading Edge, 32 (6), 674-678.

Tarque N., Lai C.G., Bozzoni F., Miccadei E., Piacentini T., Camata G. and Spacone E. 2013. Expected ground motion at the historical site of Poggio Picenze, Central Italy, with reference to current Italian building code. Engineering Geology, 166, 100-115.

Vella A., Galea P. and D'Amico S. 2013. Site frequency response characterisation of the Maltese islands based on ambient noise H/V ratios. Engineering Geology, 163, 89-100.

Vidal F. 1986. Seismotectonics of the region Betics-Alborán Sea. Thesis, University of Granada, Spain (in Spanish).

Wathelet M. 2005. Array recordings of ambient vibrations: surface-wave inversion. $\mathrm{PhD}$ thesis, University of Liège, Belgium.

Xia J., Miller R.D. and Park C.B. 1999. Estimation of near-surface shear-wave velocity by inversion of Rayleigh waves. Geophysics, 64, 691-700.

Yilmaz O. 2015. Engineering seismology with applications to geotechnical engineering. Investigation in Geophysics no. 17. Society of Exploration Geophysicists, 954. 